\title{
Pemetaan Habitat Bentik Pulau Salarangan Menggunakan Metode Object-Based Image Analysis
}

Citra Arum Sari ${ }^{1}$, Achmad Fachrudin Syah ${ }^{1 *}$

Program Studi Ilmu Kelautan Fakultas Pertanian Universitas Trunojoyo Madura

Jl. Raya Telang No 02 Kamal Bangkalan Madura 69162 Jawa Timur

*fachrudin@trunojoyo.ac.id

DOI: https://doi.org/10.21107/rekayasa.v14i1.7996

\begin{abstract}
Salarangan Island has supporting ecosystems that are seagrass and coral reefs with a high increase in biological competence. Basic information about the distribution map of benthic habitats on Salarangan Island is not yet available so that technology is needed that can provide information spatially and temporally. Citra Sentinel-2A with Lyzenga transformation in mapping benthic and shallow habitats and studying the distribution of benthic habitats on Salarangan Island, Madura. The image data used is obtained free of charge from the website earthexplorer.usgs.gov and in situ data are used for image data validation. The multiscale / OBIA classification method with the SVM algorithm is used to classify objects in the navigation column. The classification results show as many as 4 benthic habitat classes with object / OBIA classification resulting in overall certification of $69.86 \%$. Based on the classification results, the most contrasting class is the seagrass class (48.76 ha) because it has the most extensive area than the coral class (27.31\%), sand (8.94 ha) and seagrass + sand (31.85 ha).
\end{abstract}

Keyword: lyzenga algorithm, Sentinel-2A, benthic habitat, Salarangan Island

\section{PENDAHULUAN}

Indonesia merupakan negara kepulauan dengan sekitar $75 \%$ wilayahnya berupa laut dengan lebih dari 13.000 pulau, serta panjang garis pantai nomor 4 di dunia yaitu kurang lebih 81.000 km (Nurcahyo, 2018; Sutrisno, 2014). Sebagai sebuah negara kepulauan, Indonesia memiliki potensi yang luar biasa di bidang kelautan dan perikanan. Lautan Indonesia juga merupakan Marine Mega Biodiversity terbesar di dunia meliputi 8500 spesies ikan, 555 spesies rumput laut, dan 950 spesies terumbu karang dengan potensi sumber daya terumbu karang yang mencapai $85.000 \mathrm{~km}^{2}$ serta potensipotensi kelautan dan perikanan lainnya.

Salah satu wilayah Indonesia yang memiliki kondisi terumbu karang yang cukup baik adalah Pulau Salarangan yang terletak di Kepulauan Sumenep, Madura. Pulau Salarangan merupakan salah satu pulau kecil yang secara administratif berada di dusun Salarangan, Desa Paliat, Kecamatan Sapeken, Kabupaten Sumenep, Jawa Timur. Pulau kecil seperti pulau Salarangan memiliki ekosistem

\section{Article History:}

Received: July 26 ${ }^{\text {th }}$ 2020; Accepted: March, $20^{\text {th }} 2021$

Rekayasa ISSN: $2502-5325$ has been Accredited by Ristekdikti (Arjuna) Decree: No. 23/E/KPT/2019 August 8th, 2019 effective until 2023 pendukung dengan produktivitas keanekaragaman hayati yang tinggi yaitu ekosistem terumbu karang dan lamun. Kedua ekosistem tersebut merupakan komponen penyusun yang sangat penting di perairan dangkal sebagai tempat pemijahan, tempat mencari makan, tempat tinggal biota laut, sebagai pelindung pantai dari gelombang, menstabilkan sedimen, penjernih perairan, penyerap karbon, sumber material industri dan farmasi, serta pariwisata (Prawoto, 2018). Organisme lain penyusun habitat bentik yaitu rumput laut, sponge dan alga. Tipe substrat dihabitat bentik yaitu pasir, lumpur, dan pecahan karang (Anggoro, 2015; Mastu et al., 2018). Informasi tentang sebaran ekosistem penyusun perairan dangkal saat ini menjadi kajian yang sangat penting untuk menggambarkan kondisi perairan dangkal disuatu wilayah secara spasial dan temporal. Informasi tersebut dapat diperoleh dengan memanfaatkan citra satelit penginderaan jauh.

\section{Cite this as:}

Sari, C.A \& Syah, A.F. (2021). Pemetaan Habitat Bentik Pulau Salarangan Menggunakan Metode Object-Based Image Analysis. Rekayasa 14 (1). 114-120.

doi: https://doi.org/10.21107/rekayasa.v14i1.7996

(c) 2021 Citra Arum Sari, Achmad Fachrudin Syah 
Pemanfaatan data penginderaan jauh juga dapat menghemat waktu, tenaga dan biaya dibandingkan dengan teknik survei lapang (Prawoto \& Hartono, 2018). Data penginderaan jauh juga memiliki keunggulan dalam pembaruan data baik secara spasial dan temporal. Penginderaan jauh pada perairan dangkal yang memiliki air jernih, sensor citra dapat menembus hingga kedalaman 30 meter (Mumby et al., 2004). Pemetaan perairan dangkal biasanya memanfaatkan gelombang tampak $(400-750 \mathrm{~nm})$ yang terbagi pada saluran biru, hijau dan merah. Kemampuan saluran band akan dipengaruhi oleh kondisi perairan, saluran band biru dan hijau akan semakin melemah saat kondisi air keruh. Spektrum elektromagnetik dalam menembus kolom perairan dipengaruhi oleh adanya fitoplankton, partikel tersuspensi dan absorbsi oleh badan air (Hidayat, 2017). Teknologi yang semakin maju menuntut para analis dalam bidang penginderaan jauh untuk terus mengkaji teknik atau metode pengolahan data citra untuk memperoleh informasi yang tepat dan akurat. Salah satu metode pengolahan data citra adalah klasifikasi citra yang dapat dilakukan secara manual ataupun secara digital (Mastu et al., 2018).

Klasifikasi citra secara manual dilakukan dengan melihat kunci interpretasi citra yaitu rona dan warna, tekstur, bentuk, pola, situs, ukuran, asosiasi dan konvergensi bukti sedangkan klasifikasi secara digital adalah sebuah proses untuk mengelompokkan piksel kedalam kelas tertentu berdasarkan nilai kecerahan piksel (brightness value atau digital number) pada data citra (Danoedoro, 2012). Klasifikasi secara digital memiliki dua pendekatan yaitu berbasis piksel (pixel based) atau berbasis objek (object based). Klasifikasi berbasis piksel merupakan kalsifikasi yang hanya bertumpu pada nilai spektral citra. Klasifikasi ini dikembangkan oleh para analis pada citra yang biasanya pada citra beresolusi sedang (Danoedoro, 2012).

Kehadiran citra dengan resolusi tinggi juga menantang para analis untuk mengembangkan metode klasifikasi yang dikenal dengan metode berbasis objek/ Object-Based Image Analysis (OBIA). Metode OBIA merupakan paradigma baru dalam klasifikasi citra dan merupakan salah satu sub-kajian dari GIS-science yang fokus pada pengembangan metode analisis citra penginderaan jauh berbasis objek sehingga menjadi beberapa objek yang memiliki kesamaan tertentu (Navulur, 2007). Menurut Danoedoro, (2012) metode OBIA mampu mendefinisikan kelas-kelas objek berdasarkan aspek spasial dan aspek spektral secara bersamaan. Metode OBIA dilakukan dengan tahapan segmentasi citra (pixel level) menjadi segmen/ objek (object level) yang homogen dan sesuai dengan parameternya (Anggoro et al., 2017).

Penelitian terkait pemanfaatan teknologi penginderaan jauh khususnya penyedia informasi spasial habitat bentik perairan dangkal telah banyak dilakukan (Anggoro et al., 2016, 2017; Candra et al., 2018; Hafizt et al., 2017; Prabowo et al., 2018; Putra \& Nurul, 2013; Setyawan et al., 2014; Siregar, 2010; Wahiddin et al., 2015). Pemanfaatan sentinel-2A untuk pemetaan habitat bentik dilakukan oleh Mastu et al., (2018) di Pulau Wangi-wangi dengan metode OBIA (Object Based Image Analysis) serta penelitian yang dilakukan oleh (Prawoto \& Hartono., 2018) menggunakan Sentinel-2A di perairan Pulau Menjangan Kecil dan Menjangan Besar dengan metode multispektral (berbasis piksel).

Pemanfaatan data citra penginderaan jauh untuk pemetaan habitat bentik perairan dangkal seringkali dipengaruhi oleh adanya pengaruh gangguan permukaan perairan dan kedalaman perairan terhadap reflektansi dasar perairan (Lyzenga, 1981) serta penentuan metode klasifikasi citra yang dapat mempengaruhi tingkat akurasi pemetaan habitat bentik (Prayudha, 2014). Penelitian tentang penggunaan metode lyzenga pernah dilakukan oleh (Hafizt et al., 2017) dengan citra Sentinel-2A yang menghasilkan tingkat akurasi keseluruhan 23,31 \% (Isodata classification model 1 dengan DII) 83,93 \% (Isodata classification model 2 dengan DII dan RDWI).

Penerapan metode OBIA masih sangat terbatas, namun klasifikasi metode OBIA terbukti mampu meningkatkan akurasi pada pemetaan geomorfologi dan terumbu karang di tiga perairan yang berbeda dengan hasil akurasi keseluruhan 5278\% (Phinn et al., 2011). Penelitian pemetaan geomorfologi dan habitat bentik dengan metode OBIA juga menghasilkan akurasi yang lebih baik yaitu sebesar $75 \%$ dengan algoritma support vector machine (SVM) dibandingakandengan berbasis piksel yang menghasilkan akurasi keseluruhan sebesar 61\% (Anggoro et al., 2018).

Berdasarkan penelitian sebelumnya, metode yang digunakan untuk mengekstraksi informasi dari data citra perlu memperhatikan beberapa faktor yang dapat mempengaruhi hasil akurasi pemetaan habitat bentik. Perbedaan tingkat akurasi pemetaan 
habitat bentik dari penelitian yang pernah dilkukan tergantung pada lokasi, kompleksitas habitat bentik, metode klasifikasi dan skema klasifikasi (Anggoro et al., 2018). Penerapan metode OBIA diharapkan dapat meningkatkan akurasi sehingga dapat menjadi metode alternatif untuk pemetaan habitat bentik. Penelitian ini bertujuan untuk mengetahui tingkat akurasi Citra Sentinel-2A dengan transformasi Lyzenga dalammemetakan habitat bentik perairan dangkal dan mengetahui sebaran habitat bentik berdasarkan klasifikasi multiskala/OBIA dengan algoritma SVM di Pulau Salarangan, Madura.

\section{METODE PENELITIAN}

\section{Waktu dan Tempat}

Penelitian habitat bentik dilaksanakan diperairan Pulau Salarangan, Kabupaten Sumenep, Madura. Survei lapang dilakukan pada tanggal 18 - 20 September 2019. Secara geografis lokasi penelitian terletak antara $115^{\circ} 38^{\prime} 12.43^{\prime \prime}$ - 115³8'15.38" BT dan 656'3.03" - 656'14.94" LS (Gambar 1). Perairan dangkal di Pulau Salararanganmemiliki komponen habitat bentik lamun dan terumbu karang serta tipe substrat berpasir. Analisis pengolahan data lapang dilakukan di Laboratorium Penginderaan Jauh IImu Kelautan Universitas Trunojoyo Madura.

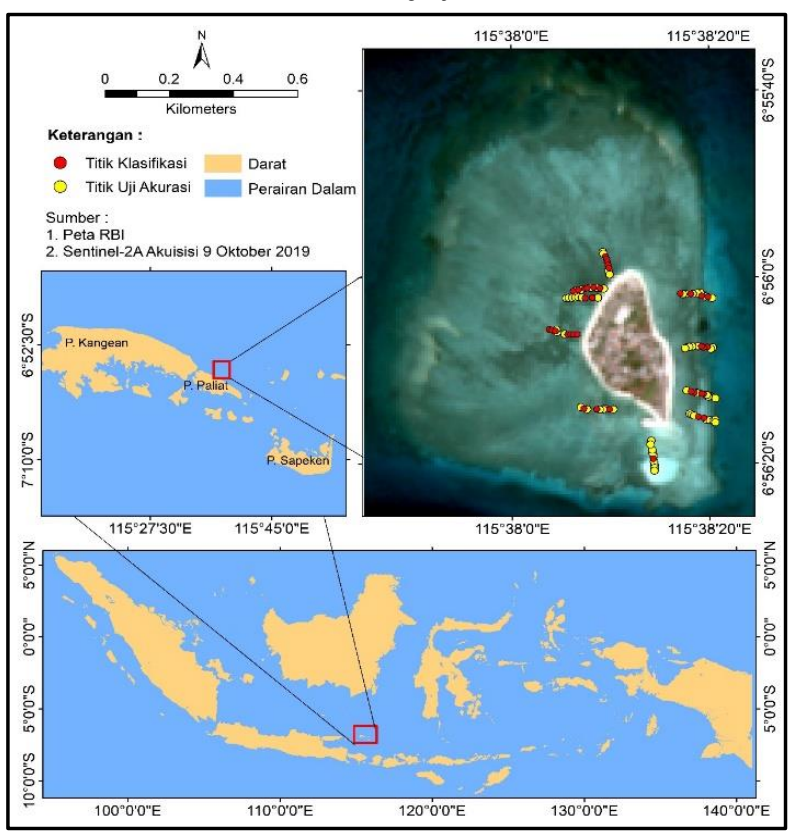

Gambar 1. Peta Lokasi Penelitian Pulau Salarangan, Sumenep, Madura

\section{Alat dan Data}

Pengolahan data citra menggunakan perangkat lunak Ecognition 649.0 dan Envi 3.1. Pembuatan peta menggunakan bantuan perangkat lunak ArcGIS 10.5 serta analisis data habitat bentik menggunakan Microsoft Office Excel. Pengambilan data habitat bentik menggunakan transek kuadrat $1 \times 1 \mathrm{~m}$ yang diletakkan pada transek sepanjang 10 meteryang tegak lurus dengan pantai dan koordinat dicatat menggunkan Global Position System (GPS). Pengambilan data kualitas air menggunkan alat DO meter, Ph meter, secchi disk dan refraktometer. Data yang digunakan pada penelitian ini adalah Sentinel-2A hasil akuisisi 9 Oktober 2019. Data citra Sentinel-2A dapat diunduh gratis pada website https://earthexplorer.usgs.gov/. Citra Sentinel-2A yang diunduh merupakan data level 1 yang berarti sudah terkoreksi geometrik dan radiometrik.

\section{Rancangan Survei Lapang}

Pengamatan lapang (ground truth habitat) dilakukan untukmemperoleh data dan informasi tentang habitat bentik dilokasi penelitian. Pengumpulan data dilakukan dengan metode Underwater Photo Transect (UPT). Metode UPT dilakukan dengan pemotretan bawah air menggunakan kamera digital bawah air atau kamera biasa yang sudah dilengkapi pelindung sehingga tahan terhadap air laut. Menurut Giyanto, (2013) ada tiga cara melakukan UPT yaitu pertama dengan panjang transek $30 \mathrm{~m}$, pemotretan dilakukan setiaprentang jarak $1 \mathrm{~m}$ dan luas frame foto yaitu $40 \times 30 \mathrm{~cm}^{2}$, kedua dengan panjang transek $50 \mathrm{~m}$, pemotretan dilakukan setiap rentang jarak $1 \mathrm{~m}$ dan luas frame foto yaitu $40 \times 30 \mathrm{~cm}^{2}$ serta ketiga panjang transek $50 \mathrm{~m}$, pemotretan dilakukan setiap rentang jarak $1 \mathrm{~m}$ dan luas frame foto yaitu $58 \times 44 \mathrm{~cm}^{2}$ (Gambar 2).

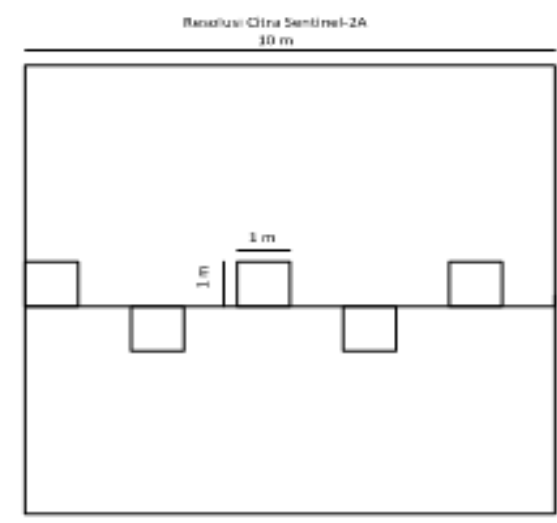

Gambar 2. Transek Kuadrat Pengambilan Data Lapangan

Metode UPT yang digunakan dalam penelitian ini ada sedikit modifikasi yaitu pemotongan panjang transek menjadi 10 meter yang disesuaikan dengan 
resolusi citra Sentinel-2A serta pemotretan dilakukan setiap rentang jarak $1 \mathrm{~m}$ dan ground truth habitat menggunakan transek kuadrat $1 \times 1 \mathrm{~m}$ sebagai luas frame foto (English et al., 1997).

\section{Koreksi Kolom air}

Koreksi kolom air dibutuhkan ketika ingin memetakan habitat dasar laut perairan dangkal. Dalam penelitian ini, koreksi kolom air dilakukan dengan memodifikasi algoritma yang telah dikembangkan oleh Lyzenga, (1981). Kombinasi untuk koreksi kolom air biasanya menggunakan band green dan blue. Formulasi Algoritma yang dikembakan oleh Lyzenga, (1981) yaitu:

$$
\begin{gathered}
\text { Index }_{i j}=\ln B i-((k i / k j) x \ln B j) \\
K i / k j=a+\left(a^{2}+1\right)^{1 / 2} \\
a=\left(\operatorname{var} B i-\operatorname{var} B j /\left(2^{*} \operatorname{cov} B i B j\right)\right.
\end{gathered}
$$

Keterangan :

Index $x_{i j}$ : water depht invariant bottom index

$\mathrm{Bi} \quad$ : saluran $\mathrm{i}$

$\mathrm{Bj} \quad$ : saluran $\mathrm{j}$

$\mathrm{Ki} / \mathrm{kj}$ : rasio Koefisien pelemahan kolom air antara saluran i dan $\mathrm{j}$

\section{Algoritma Klasifikasi Support Vector Machine (SVM)}

Algoritma SVM adalah salah satu klasifikasi secara terbimbing dengan input thematic layer dari pengamatan lapang (Anggoro et al., 2017). Algoritma SVM memiliki konsep sederhana yaitu mencari hyperlane (garis) baik sebagai pemisah dua kelas dengan memaksimalkan margin antar kelas tersebut. Algoritma ini dapat bekerja secara efektif pada jenis data yang memiliki resolusi tekstur rendah (Wahiddin et al., 2015). Persamaan algoritma SVM tersebut adalah (Tzotsos, 2006):

Keterangan $: i$,

$$
f(x): \sum_{i \in S} \lambda_{i} y_{i} K\left(x_{i} x\right)+w_{0}
$$

$\mathrm{K}$ : fungsi kernel

$x_{\mathrm{i}} \quad$ : Sampel pelatihan

$\lambda_{i} \quad$ : lagrange

$S$ : bagian dari sampel pelatihan yang sesuai dengan pengganda lagrange non-zero

$w_{0}$ : Parameter hyperplane

\section{Klasifikasi Berbasis Objek}

Metode klasifikasi berbasis objek atau OBIA (Object-Based Image Analysis) dilakukan dengan cara melakukan segmentasi dengan menggunakan algoritma MRS (multiresolution segmentation). Segmentasi dengan algoritma ini didasarkan pada tiga parameter yaitu paramater skala (scale), bentuk (shape) dan kekompakan (compactness). Ketiga parameter tersebut akan dijadikan sebagai input fiture untuk membangun rule set pada pohon proses (Process tree). Rule set yang dibangun merupakan kumpulan dari beberapa algoritma yang digunakan untuk mengklasifikasikan objek ke dalam kelas-kelas tertentu (Anggoro, 2015; Anggoro et al., 2017). Algoritma MRS (Multi Resolution Segmentation) memiliki persamaan sebagai berikut :

$$
S_{f}=w_{\text {colour }} \times h_{\text {colour }}+\left(1-w_{\text {colour }}\right) \times h_{\text {shape }}
$$

Keterangan :

$\mathrm{S}_{\mathrm{f}} \quad$ : Fungsi segmentasi

$\mathrm{w}_{\text {colour }}$ : Bobot parameter warna

$\mathrm{h}_{\text {colour }}$ : Parameter warna

$h_{\text {shape }}:$ Bobot parameter bentuk

$\mathrm{w}_{\text {colour }}$ : Parameter bentuk

\section{Skema Klasifikasi}

Skema klasifikasi ditentukan untuk mengkelaskan tipe-tipe habitat bentik secara terstruktur. Skema klasifikasi digunakan untuk memandu batasan dan definisi habitat bentik dalam proses pembuatan peta (Mastu et al., 2018). Tahap ini menjadi penting untuk pengguna peta dalam memahami bagaimana sistem klasifikasi sebagai struktur dalam mendefenisikan setiap kelas (Zitello et al., 2009). Skema klasifikasi dibagi menjadi 2 level yaitu klasifikasi pada level 1 (reef level) dan level 2 (habitat bentik).

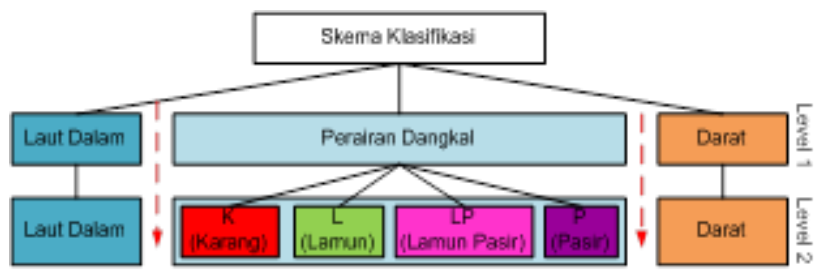

Gambar 3. Skema Klasifikasi 2 Level

\section{HASIL DAN PEMBAHASAN \\ Rancangan Survei Lapang}

Rancangan survei lapang digunakan untuk menentukan titik pengambilan data habitat bentik. Rancangan survei lapang tersebut menghasilkan 8 kelas diperairan dangkal yang dapat diklasifikasikan ulang sesuai dengan data lapang yang diperoleh (Gambar 4). Titik pengambilan data dilakukan dengan mengelilingi pulau Salarangan agar mendapatkan keterwakilan kelas habitat bentik dengan jumlah 110 titik. 


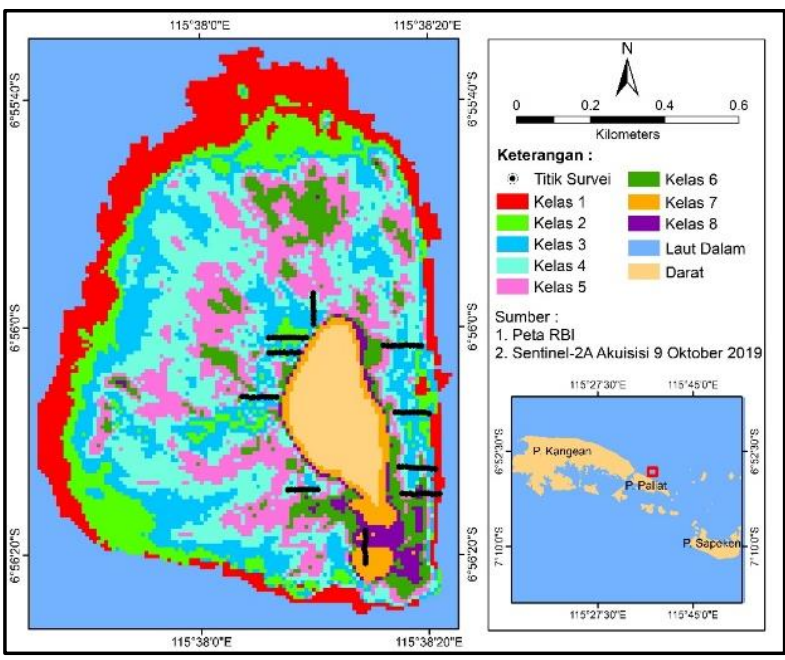

Gambar 4. Hasil Isodata dan Plot Titik Survei Lapang

\section{Koreksi Kolom Air}

Koreksi kolom air digunakan untuk memperbaiki kualitas citra. Koreksi kolom air memiliki nilai $R$ square yang tinggi (Gambar 5). Hal ini menunjukkan bahwa data tersebut dapat digunakan untuk membangun persamaan pada koreksi kolom air lihat. Nilai $R$-square dalam penelitian ini menggambarkan hubungan linear antara saluran inframerah dekat dengan saluran tampak.

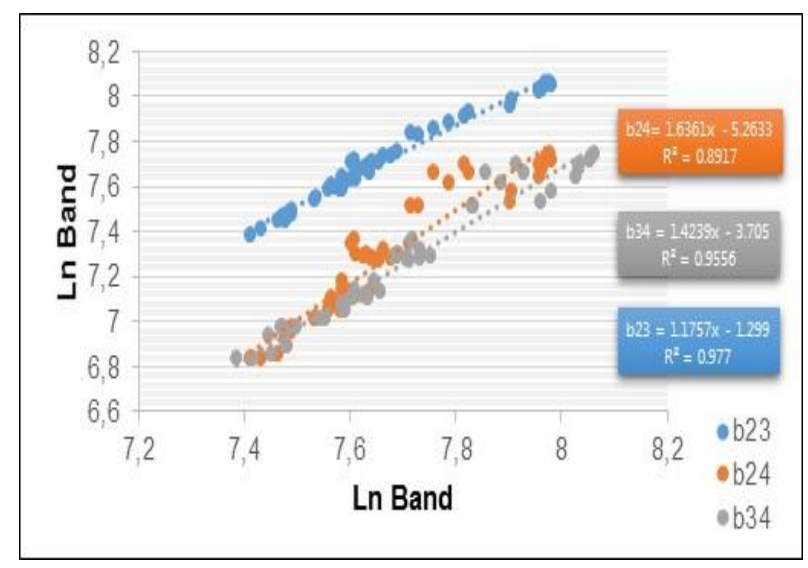

Gambar 5. Grafik Hubungan Linier Saluran Inframerah Dekat dengan Saluran Tampak

Informasi dasar laut dapat ditentukan dari nilai koefisien atenuasi (pelemahan) kolom air antara saluran $i$ dan $j$ (ki/kj) (Prayudha, 2014). Nilai (ki/kj) diperoleh dari pemilihan ROI atau training area objek pasir pada kedalaman yang berbeda. Nilai pelemahan sinar matahari yang menembus keperairan ditentukan dari nilai varian dan kovarian (Tabel 1). Perairan yang jernih memiliki nilai pelemahan energi yang semakin rendah. Rasio koefisien attenuasi merupakan perbandingan koefisien atenuasi tiap pasang band yang digunakan serta nilai statistik yang dihasilkan akan memberikan nilai pantulan baru yaitu nilai pantulan objek pada dasar perairan (Prawoto \& Hartono, 2018).

Tabel 1. Hasil Perhitungan Nilai Varian dan Kovarian

\begin{tabular}{llllll}
\hline Varian & Nilai & Kovarian & Nilai & $\mathrm{A}$ & $\mathrm{ki} / \mathrm{kj}$ \\
\hline Band 2 & 0.026 & $\mathrm{~b} 2 \mathrm{~b} 3$ & 0.030 & -0.180 & 0.835 \\
Band 3 & 0.036 & b2b4 & 0.041 & -0.625 & 0.554 \\
Band 4 & 0.078 & b3b4 & 0.051 & -0.402 & 0.675 \\
\hline
\end{tabular}

Tabel 2. Modifikasi dari Persamaan Algoritma Lyzenga

\begin{tabular}{|c|c|}
\hline Band & Algoritma \\
\hline b2b3 & $\operatorname{alog}(B 2)-(0.835839 *(\operatorname{alog}(B 3)))$ \\
\hline b2b4 & $\operatorname{alog}(B 2)-\left(0.554202^{*}(\operatorname{alog}(B 4))\right)$ \\
\hline b3b4 & $\operatorname{alog}(B 3)-\left(0.675509^{*}(\operatorname{alog}(B 4))\right)$ \\
\hline
\end{tabular}

Algoritma pada Tabel 2 ditransformasikan ke data citra untuk koreksi kolom air. Hasil data citra yang telah terkoreksi kolom air akan digunakan untuk mengklasifikasikan habitat bentik. Data citra yang telah dikoreksi kolom air dan yang belum terkoreksi memiliki perbedaan yang jelas yang dapat diihat secara visual yaitu perubahan warna pada objek yang dapat dilihat pada Gambar 6. Tiga pasang band DII (Depht Invariant Index) yang dihasilkan dari citra Sentinel-2A akan digunakan sebagai input data feature untuk proses klasifikasi habitat bentik.

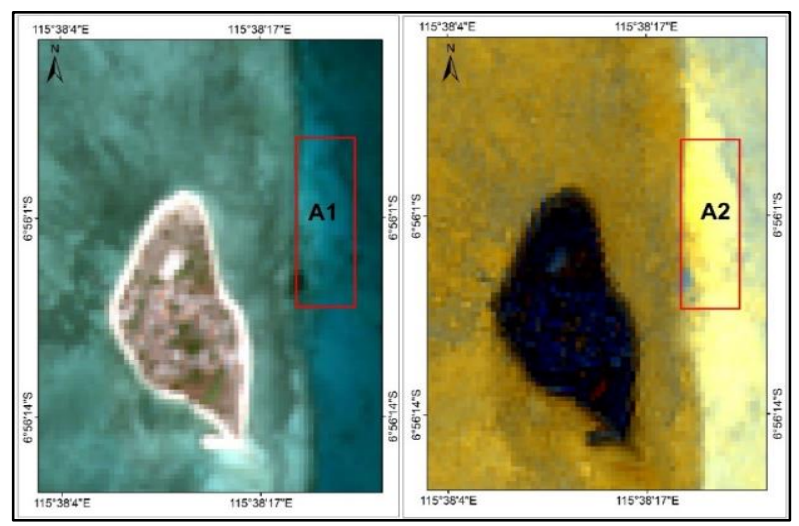

Gambar 6. a) Citra yang Belum Terkoreksi (A1), b) Citra yang Terkoreksi Kolom Air (A2)

Sensor citra yang mengenai kolom air akan memantulkan efek pantulan yang lebih gelap saat mengenai objek yang sama pada kedalaman yang berbeda. Kode A pada Gambar 6 adalah objek pasir dengan kedalaman yang berbeda. Citra yang belum terkoreksi (A1) menunjukkan pasir yang berada lebih dalam dengan warna yang cenderung kebiruan sedangkan pada citra yang terkoreksi (A2) menunjukkan pasir dengan kedalam yang berbeda memiliki warna yang sama dan rona yang cerah serta tampilan visual yang cenderung sama. 


\section{Skema Klasifikasi}

Hasil pengamatan pada 110 titik lapang diperoleh sebanyak 4 komponen habitat bentik. Data lapang tersebut berupa sampel foto transek kuadrat habitat bentik disetiap titik lokasi pengamatan. Empat habitat bentik yang diperoleh yaitu lamun $(\mathrm{L})$, pasir $(\mathrm{P})$, karang $(\mathrm{K})$ dan lamun + Pasir (LP) disajikan pada Tabel 3.

Tabel 3. Penamaan, Deskripsi dan Kode Kelas Habitat Bentik

\begin{tabular}{ccc}
\hline $\begin{array}{c}\text { Kelas Habitat } \\
\text { Bentik }\end{array}$ & Deskripsi & Kode \\
\hline Karang & Dominan karang & $\mathrm{K}$ \\
Lamun & Dominan lamun & $\mathrm{L}$ \\
Pasir & Dominan pasir & $\mathrm{P}$ \\
& Dominan lamun campur & \\
Lamun + Pasir & pasir & LP \\
\hline
\end{tabular}

Skema klasifikasi disesuaikan dengan komposisi penyusun habitat bentik yang dominan pada perairan dangkal dikarenakan penentuan skema klasifikasi habitat bentik sampai saat ini tidak memiliki ketentuan atau standarisai yang baku (Mastu et al., 2018). Beberapa penelitian tentang penentuan skema klasifikasi telah banyak dilakukan dan memiliki hasil skema yang berbeda-beda seperti skema klasifikasi yang dikembangkan oleh Siregar, (2010) menghasilkan 6 kelas, Anggoro et al., (2018) menghasilkan 8 kelas, Prawoto \& Hartono, (2018) menghasilkan 4 kelas, Setyawan et al., (2014) menghasilkan 7 kelas dan Mastu et al., (2018) menghasilkan 12 kelas habitat bentik. Penentuan skema klasifikasi pada penelitian ini dapat juga berbeda dengan skema klasifikasi habitat bentik perairan dangkal ditempat lain dikarenakan kompleksitas habitat bentik berbeda-beda disetiap daerah. Data lapang yang diperoleh dibagi menjadi dua yaitu 37 titik sebagai data ROI pada proses klasifikasi dan 73 titik sebagai data untuk uji akurasi hasil klasifikasi (Tabel 4).

Tabel 4. Pembagian Titik Sampel Uji Akurasi dan Klasifikasi

\begin{tabular}{ccc}
\hline Kelas & Uji Akurasi & Klasifikasi \\
\hline Karang & 20 & 5 \\
Lamun & 33 & 26 \\
Pasir & 10 & 2 \\
Lamun + Pasir & 10 & 4 \\
\hline
\end{tabular}

\section{Klasifikasi Berbasis Objek (OBIA)}

Segmentasi merupakan proses dasar klasifikassi citra berbasiss objek. Segmentasi ini menggunakan agoritma multiresolution segmentation (MRS). Proses segmentasi pada level 1 menghasilkan sebanyak 1.1882 segmen/objek. Skala segmentasi pada level 1 yang digunakan adalah skala 10. Pada level 2 klasifikasi menggunakan skala 5 dan menghasilkan objek sebanyak 3966 segmen/objek. Skala yang digunakan tersebut merupakan hasil dari trial and error. Skala segmentasi digunakan sebagai parameter untuk membentuk objek pada citra baik jumlah ataupun bentuk objek (Mastu, 2018). Pengaruh skala segmentasi juga telah dibuktikan dari hasil penelitian Wahiddin, (2015) yaitu skala segmentasi dapat mempengaruhi bentuk, ukuran, dan jumlah objek yang dihasilkan. Menurut Anggoro, (2015) jumlah objek akan lebih banyak dihasilkan di wilayah yang memiliki heterogenitas objek dari pada wilayah yang memiliki homogenitas objek. Homogenitas dan heterogenitas objek akan mempengaruhi jumlah dan ukuran bentuk objek pada citra satelit. Hasil segmentasi pada level 1 dan level 2 dengan skala 10 dan 5 dapat dilihat pada Gambar 7. Hasil segmentasi yang telah sesuai akan digunakan untuk proses klasifikasi citra.

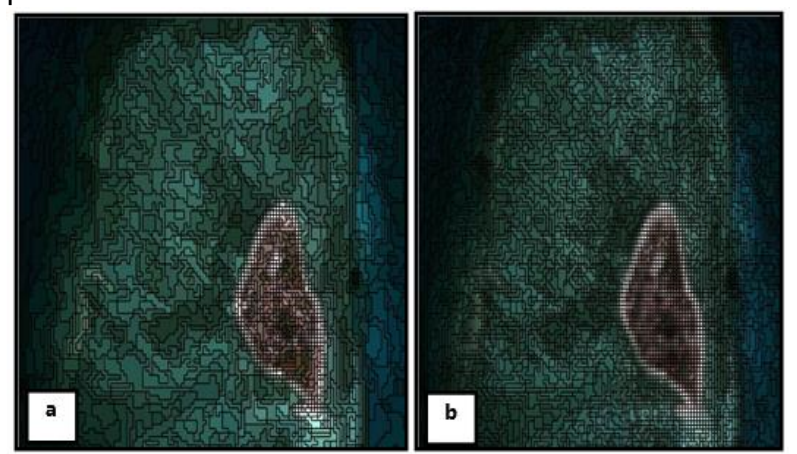

Gambar 7. Hasil Segmentasi a. Skala 10; b. Skala 5

Klasifikasi pada level 1 atau reef class akan menghasilkan 3 kelas yaitu darat, perairan dangkal dan perairan dalam. Hasil dari level 1 digunakan untuk mengambil wilayah perairan dangkal sebagai batasan untuk klasifikasi level 2 yaitu klasifikasi habitat bentik. Metode yang digunakan pada level 1 yaitu contextual editing, dimana metode tersebut berdasarkan aspek spasial dan spektral dengan menentukan nilai thereshold dari fitur yang tepat pada setiap kelas (Trimble, 2014).

Pada klasifikasi level 2 batas area untuk klasifikasi habitat bentik adalah perairan dangkal hasil dari level 1. Perairan dangkal pada level 2 dilakukan segmentasi dengan skala 5 untuk mendapatkan kelas habitat bentik. Hasil segmentasi kemudian diklasifikasi dengan metode terbimbing yang menerapkan algoritma SVM. Input thematic layer menggunakan data skema klasifikasi yaitu berupa data ROI dari pengamatan lapang dan juga 
secara visual. Input fitur yang digunakan yaitu nilai dari layer mean dari semua band sinar tampak serta hasil dari tiga kombinasi pasangan band hasil koreksi kolom air. Level 2 dengan metode berbasis objek menghasilkan luas karang sebesar 27,31 $\mathrm{Ha}$, kelas lamun sebesar 48,76 $\mathrm{Ha}$, kelas pasir sebesar 8,94 Ha, dan kelas Lamun+pasir sebesar 31,85 $\mathrm{Ha}$ (Gambar 8).

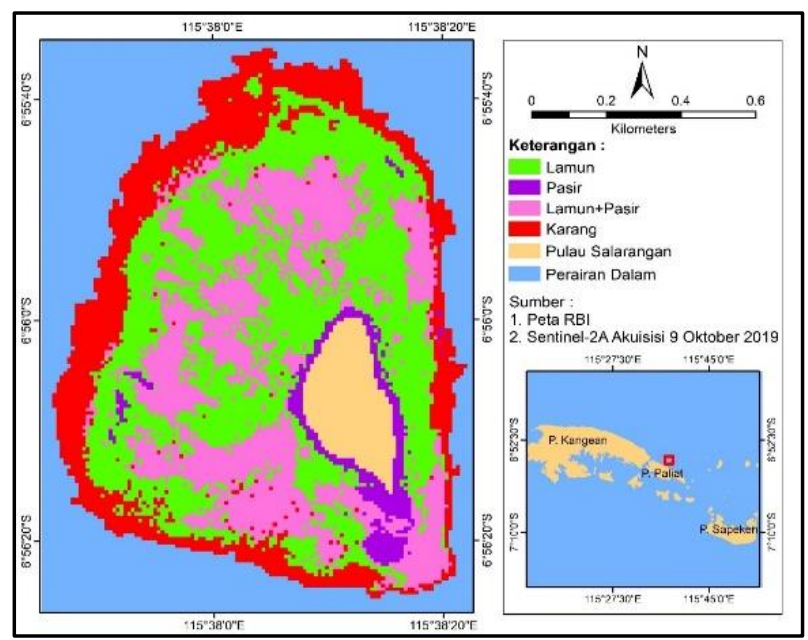

Gambar 8. Kelas Habitat Bentik Hasil Klasifikasi Level 2

Hasil uji akurasi dengan matrik kesalahan yaitu akurasi keseluruhan (OA) sebesar 69,86\%. Nilai PA (producer accuracy) dan UA (user accuracy) antara 27 - 100\% yang menunjukkan bahwa ada beberapa habitat bentik yang dapat dipetakan dengan baik. Kelas bentik yang dipetakan kurang baik yaitu Lamun+pasir dengan akurasi sebesar 27,78\%. Rendahnya akurasi dapat disebabkan oleh tingginya kompleksitas habitat bentik serta akurasi GPS dengan resolusi spasial citra yang digunakan. Tingkat akurasi pemetaan habitat bentik menurut SNI : 2011 yaitu sebesar $60 \%$.

\section{KESIMPULAN}

Citra Satelit Sentinel-2A dapat digunakan memetakan habitat bentik di Pulau Salarangan, Madura dengan baik. Hasil skema klasifikasi sebanyak 4 kelas habitat bentik dengan klasifikasi berbasis objek/OBIA menghasilkan akurasi keseluruhan sebesar 69,86\%. Berdasarkan hasil klasifikasi, kelas yang paling mendominasi adalah kelas lamun (48,76 ha) karena memiliki luasan yang paling luas dari pada kelas karang (27,31\%), pasir (8,94 ha) dan lamun+pasir (31,85 ha). Perlu adanya penelitian lebih lanjut terkait dengan citra Sentinel2A dengan penerapan beberapa algoritma dan pengujian parameter para metode klasifikasi berbasis objek/OBIA. Hal lain yang juga perlu diperhatikan yaitu teknik, jumlah serta penyebaran pengambilan titik lapang.

\section{DAFTAR PUSTAKA}

Anggoro, A., Siregar, V. P., \& Agus, S. B. (2016). The Effect of Sunglint on Benthic Habitats Mapping in Pari Island Using Worldview-2 Imagery. Procedia Environmental Sciences, 33(1), 487-495. https://doi.org/10.1016/j.proenv.2016.03.101

Anggoro, A., Sumartono, E., Siregar, V. P., Agus, S. B., Purnama, D., Supriyono, S., Puspitosari, D. A., Listyorini, T., Sulistyo, B., \& Parwito, P. (2018). Comparing Object-based and Pixel-based Classifications for Benthic Habitats Mapping in Pari Islands. Journal of Physics: Conference Series, 1114(1), 1-7. https://doi.org/10.1088/17426596/1114/1/012049

Anggoro, A. (2015).Pemetaan Zona Geomorfologi Dan Habitat Bentik Menggunakan Citra Worldview-2 Dengan Metode Obia Di Gugus Pulau Pari. Thesis. Institut Pertanian Bogor.

Anggoro, A., Siregar, V. P., \& Agus, S. B. (2017). Klasifikasi Multikskala Untuk Pemetaan Zona Geomorfologi Dan Habitat Bentik Menggunakan Metode Obia Di Pulau Pari (Multiscale Classification for Geomorphic Zone and Benthic Habitats Mapping Using Obia Method in Pari Island). Jurnal Penginderaan Jauh Dan Pengolahan Data Citra Digital, 14(2), 89-93. https://doi.org/10.30536/j.pjpdcd.1017.v14.a26 22

Burnett, C., \& Blaschke, T. (2003). A multi-scale segmentation/object relationship modelling methodology for landscape analysis. Ecological Modelling, 168(3), 233-249. https://doi.org/10.1016/S0304-3800(03)00139$\mathrm{X}$

Candra, I. D., Siregar, V. P., \& Agus, S. B. (2018). Pemetaan Zona Geomorfologi Dan Habitat Bentik Di Pulau Kotok Besar Menggunakan Klasifikasi Berbasis Objek. Jurnal Teknologi Perikanan Dan Kelautan, 8(2), 209-219. https://doi.org/10.24319/jtpk.8.209-219

Congalton, R. G., Green, K. (2009). Assessing the accuracy of remotely sensed data principles and practices. In Second Edition. Taylor \& Francis Group, LCC. 
Danoedoro, P. (2012). Pengantar Penginderaan Jauh Digital. ANDI Yogyakarta.

English, S., Wilkinson, C., \& Baker, V. (1997). Survey Manual for Tropical Marine Resources. Australia (AU): Mc Graw Publication.

Giyanto. (2013). Metode Transek Foto Bawah Air untuk Penilaian Kondisi Terumbu Karang. Oseana, 28(1), 47-61.

Hafizt, M., Iswari, M. Y., \& Prayudha, B. (2017). Kajian Metode Klasifikasi Citra Landsat-8 untuk Pemetaan Habitat Bentik di Kepulauan Padaido, Papua Assessment of Landsat-8 Classification Method for Benthic Habitat Mapping in Padaido Islands , Papua Abstrak Pendahuluan Metodologi. Oseanologi Dan Limnologi Di Indonesia, 2(June 2015), 1-13. https://jurnaloldi.or.id/index.php/oldi/article/view/69/67

Hafizt, M., Manessa, M. D. M., Adi, N. S., \& Prayudha1, B. (2017). Benthic Habitat Mapping by Combining Lyzenga's Optical Model and Relative Water Depth Model in Lintea Island, Southeast Sulawesi Benthic Habitat Mapping by Combining Lyzenga' s Optical Model and Relative Water Depth Model in Lintea Island, Southeast. 0-10.

Hidayat, A. M. (2017). Pemetaan habitat bentik perairan dangkal pulau opak berbasis objek dan piksel menggunakan citra satelit spot-7.

Lillsand, T. M., \& Kiefer, R. W. (1979). Remote Sensing and Image Interpretations. New York: John Wiley and Sons.

Lyzenga, D. R. (1981). Remote sensing of bottom reflectance and water attenuation parameters in shallow water using aircraft and landsat data. International Journal of Remote Sensing, 2(1), 7182.

https://doi.org/10.1080/01431168108948342

Mastu, L. O. K. (2018). Pemetaan Habitat Bentik Berbasis Objek Menggunakan Citra Unmanned Aerial Vehicle (UAV) dan Satelit Sentinel-2 di Perairan Pulau Wangi-Wangi Kabupaten Wakatobi. Theisi. Institut Pertanian Bogor Bogor.

Mastu, L. O. K., Nababan, B., \& Panjaitan, J. P. (2018). Pemetaan Habitat Bentik Berbasis Objek Menggunakan Citra Sentinel-2 Di Perairan Pulau Wangi-Wangi Kabupaten Wakatobi. Jurnal Ilmu Dan Teknologi Kelautan Tropis, 10(2), 381-396. https://doi.org/10.29244/jitkt.v10i2.21039
Mumby, P. J., Skirving, W., Strong, A. E., Hardy, J. T., LeDrew, E. F., Hochberg, E. J., Stumpf, R. P., \& David, L. T. (2004). Remote sensing of coral reefs and their physical environment. Marine Pollution Bulletin, 48(3-4), 219-228. https://doi.org/10.1016/j.marpolbul.2003.10.031

Navulur, K. (2007). Multispectral Image Analysis Using the Objek-Oriented Paradigm. Taylor \& Francis Group, LCC.

Nurcahyo, O. H. (2018). Pendidikan Multikultural di Indonesia: Analisis Sinkronis dan Diakronis. Jurnal Pendidikan, Sosiologi Dan Antropologi, 2(1), 105115.https://doi.org/10.1017/CBO978110741532 4.004

Phinn, S. R., Roelfsema, C. M., \& Mumby, P. J. (2011). Multi-Scale, Object-Base Image Analysis for mapping Geomorphic and Ecological Zone on Coral Reefs. Int J Remote Sens, 333768-3797.

Prabowo, N. W., Siregar, V. P., \& Agus, S. B. (2018). Classification of Benthic Habitat Based on Object With Support Vector Machines and Decision Tree Algorithm Using Spot-7 Multispectral Imagery in Harapan and Kelapa Island. Jurnal Ilmu Dan Teknologi Kelautan Tropis, 10(1), 123134.

https://doi.org/http://dx.doi.org/10.29244/jitkt. v10i1.21670

Prawoto, C. D., \& Hartono. (2018). Pemetaan Habitat Bentik dengan Citra Multispektral Sentinel-2a di Perairan Pulau Menjangan Kecil dan Menjangan Besar, Kepulauan Karimunjawa. Jurna Bumi Indonesia, 7(3), 2-8.

Prayudha, B. (2014). Panduan Teknis Pemetaan Habitat Dasar Perairan Laut Dangkal (Suyarso (ed.); Issue 1). Coremap CTI LIPI, Jakarta.

Putra, F. M. G. P., \& Khakhim, N. (2013). Pemetaan Habitat Bentik Menggunakan Citra Quickbird Di Sebagian Pulau Kemujan, Kepulauan Karimunjawa. Jurnal Bumi Indonesia, 3(2), 2-12. https://doi.org/10.1017/CBO9781107415324.00 4

Setyawan, I. E., Siregar, V. P., Pramono, G. H., \& Yuwono, D. M. (2014). Pemetaan Profil Habitat Dasar Perairan Dangkal Berdasarkan Bentuk Topografi: Studi Kasus Pulau Panggang, Kepulauan Seribu Jakarta. Majalah Ilmiah Globë Volume, 16(2), 125- 
132.https://doi.org/10.1080/0014013820892503 2

Siregar, V. P. (2010). Pemetaan Substrat Dasar Perairan Dangkal Karang Congkak dan Lebar Kepulauan Seribu Menggunakan Citra Satelit Quick Bird. Jurnal Ilmu Dan Teknologi Kelautan Tropis, 2(1), 19-30.

Sutrisno, E. (2014). Implementasi Pengelolaan Sumber Daya Pesisir Berbasis Pengelolaan Wilayah Pesisir Secara Terpadu Untuk Kesejahteraan Nelayan (Studi di Perdesaan Nelayan Cangkol Kelurahan Lemahwungkuk Kecamatan Lemahwungkuk Kota Cirebon). Jurnal Dinamika Hukum, 14(1), 1-12.

Trimble. (2014). Ecognition Developer: User Guide (Issue March). Trimble Germany Gmbh. Munchen.

Tzotsos, A. (2006). a Support Vector Machine Approach for Object Based Image. Proceedings of 1st International Conference on Object-Based Image Analysis, Negnevitsky, 45.
Wahiddin, N. (2015). Klasifikasi Ekosistem Terumbu Karang Berbasis Objek dan Piksel di Pulau Morotai. Disertasi. Institut Pertanian Bogor. https://doi.org/10.1145/3132847.3132886

Wahiddin, N., Siregar, V. P., Nababan, B., Jaya, I., \& Wouthuyzen, S. (2015). Object-based Image Analysis for Coral Reef Benthic Habitat Mapping with Several Classification Algorithms. Procedia Environmental Sciences, 24 , 222-227. https://doi.org/10.1016/j.proenv.2015.03.029

Zitello, A. G., Bauer, L. J., Battista, T. A., Mueller, P. W., Kendall, M. S., \& E, M. M. (2009). ShallowWater Benthic Habitats of St John, U.S. Virgin Islands. NOAA Technical Memorandum NOS NCCOS 96, 53. 